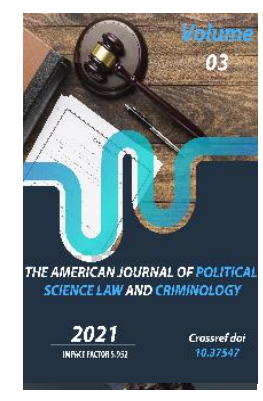

\title{
Issues Of Protection And Enforcement Of The Rights And Interests Of The Beneficiary
}

\author{
Bakhromjon Topildiev \\ Doctor Of Juridical Science, Professor, Civil Law Department Of Tashkent State University Of \\ Law, Tashkent, Uzbekistan
}

Journal Website:

http://theamericanjour nals.com/index.php/taj pslc

Copyright: Original content from this work may be used under the terms of the creative commons attributes 4.0 licence.

\section{ABSTRACT}

The subjects of a contract of trust management of property have clear rights and obligations under the contract. First of all, the trustee is the one who has to think about the rights and obligations of the party "performing the main function" in this legal relationship, and the continuation of the contractual relationship depends on his actions. The article discusses the issues of protection and observance of the rights and interests of the beneficiary.

\section{KEYWORDS}

The trust management agreement, contract, founder and the beneficiary, Civil Code.

\section{INTRODUCTION}

The subjects of a contract of trust management of property have clear rights and obligations under the contract. In most cases, the content of the contract also constitutes the powers of the trustee under the contract. As long as the property is transferred to a trustee, the trustee has the right to take any legal and practical action in the best interests of the beneficiary in respect of that property under the trust management agreement as long as the trustee controls the property. The law or contract may provide for restrictions on certain actions for the trust management of property.

According to E. A. Sukhanov, although the trustee exercises the powers (warrant) of the owner, trustee does not receive these rights on the basis of waiver of the claim from the owner. The owner-founder gives the manager the opportunity to exercise only his rights, not his own. The same situation arises in the management of property rights. In this case, 
as well, the manager acquires the opportunity to exercise the powers of the authorized person, and the rights themselves remain in the possession of the authorized person. In the cases specified, the manager acts as the owner, even though manager is not the owner. After all, the manager is in charge of the property of another on behalf of the owner or the person he represents, not on his own behalf [1].

V. A. Dozortsev suggests distinguishing the rights and obligations of a trust manager from his rights and obligations to third parties [2].

In addition to these considerations, it should be noted that the powers of the trust manager include not only the exercise of the rights and interests of the founder of the management of property management, but also the implementation of actions aimed at profit from the property. As a general rule, the primary responsibility of a trustee is to properly manage the property entrusted to him [3].

\section{THE MAIN PART}

The management of entrusted property means the development of the property in the interests of the founder and the beneficiary, the development of its benefits, the successful and reliable operation of the business, the operation of the law and the maximum protection of the property from rapid collapse. income. In this sense, the trust management must obtain an income not less than the previously received profit from the property or record the result agreed by the parties in the contract. For instance, if before the transfer to the trust management the annual income of the enterprise was 25 million
Uzbek soums, the result of the trust management is not less than 25 million Uzbek soums or less according to the agreement of the parties.

A trustee must demonstrate high professionalism in property management, fully demonstrate his knowledge, skills and abilities in a particular field, protect the entrusted property as his own property and, most importantly, keep in mind the interests of the founder and beneficiary [4].

In doing so, trustee shall take all measures to ensure that the value of the property entrusted to him does not fall. For example, when the share price falls on the stock exchange, the trustee must take all necessary measures to raise the share price.

Obligations of the trust manager to manage the property, must first take measures to protect the property. However, it is also important to ensure that such measures are put into practice. However, it should be noted that these cases are not reflected in the civil legislation of our country. First of all, it is expedient to include in Article 857 of the Civil Code of the Republic of Uzbekistan, the fifth part of the Rules of insurance of property transferred to trust management as the most important practical action with respect to the custody of the property entrusted to the trust manager and the future loss of such property. In our opinion, this norm should be expressed in the following sense:

- the trustee must fully insure the property transferred to trust management at the expense of this property. If the property is transferred to a trust manager to carry out business activities, then the trust manager 
must also insure the business risk at the expense of the property under trust management.

If the insurance costs are incurred at the expense of the trustee, these costs can then be recovered from the property under trust management.

The introduction of such a norm in the Civil Code, along with the protection of the interests of the owner and his property rights in respect of the property entrusted to trust management, prevents future property losses. At the same time, entrepreneurial risk, in this sense, entrepreneurial risk, is the risk that the entrepreneur's counterparties will violate their obligations or fail to receive the expected income from the business due to changes in the conditions of the business as a result of risk-based business activities. and the risk of civil liability, here, liability for obligations arising from damage to life, health or property of other persons, and in cases provided by law, as well as contractual liability insurance should always be considered as an obligation of a trustee to protect property under trust management need [5].

The question of who bears the risk of accidental loss of property is also important in a trust management relationship. After all, while a trustee must take practical and legal action against the property in the best interests of the owner and the beneficiary, he or she will also need to take adequate care of the property. In this regard, it should be strengthened in the Civil Code who should be responsible for the risk of accidental loss of property under trust management. In this case, it would be expedient to include the following rule as part 6 of Article 857 of the Civil Code:

- the risk of accidental loss or damage to the property transferred to the trust management is the responsibility of the trust manager, unless otherwise provided by law or contract.

It is well known that a trustee acts in the interests of the founder and the beneficiary. In this regard, the founder of the management and the beneficiary have the right to be aware of the actions taken by the trustee in the management. This obliges the trustee to submit a report on its activities to the founder of the management and the beneficiary within the period and in the manner prescribed by the trust management agreement.

Article 857 of the Civil Code defines the rights and obligations of a trust manager in respect of the property entrusted to him. In accordance with this article, the trustee exercises the rights of the owner in respect of the property entrusted to trust management within the limits provided by law and the contract of trust management of property.

In order to protect the property in trust, the trustee has the right to demand redress for any violation of his rights. In this case, the trustee has the rights of the owner of the property as the holder of the title and has the right to use any civil law methods in the protection of the property entrusted to the trust management $[6,7]$.

According to Article 228 of the Civil Code, a trustee has the right to demand (vindication) of the property entrusted to him from the illegal possession of another person. 
The claim of the owner to seize his property from another person illegally (vindication is derived from the Latin word "vim / dicere", meaning "I declare the use of force") is a noncontractual claim of the legal owner to return the property in kind from the illegal owner. Our legislation provides for the existence of several circumstances for the initiation of a vindication claim. They are as follow:

First, the owner must be deprived of the actual ownership of the property that has fallen out of his possession. Otherwise, other methods of protecting property rights are used.

Second, property deprived of ownership must be retained in kind and be in the actual possession of another. Otherwise, other methods of protecting property rights are used here as well. For example, a claim for damages.

Third, vindication focuses only on the return of an individually marked item. In this case, it is necessary to distinguish between items of the same type with an individual (individually) designated item. If it is possible to distinguish the property of the real owner from the same type of property, then vindication is also applied to this type of property. If segregation is not possible, a claim arising from unjust enrichment, not a vindication claim, should be applied.

Fourth, the vindication claim is noncontractual and protects property rights as an absolute subjective right [8].

If the property was paid for by a person who did not have the right to transfer it to another person, the recipient did not know and could not know (fair owner), the property was lost by the owner or by the person who gave it to the owner, or from the owner or he - if the property was stolen from the person who transferred it or otherwise lost their possession, the owner has the right to demand it from the person who received the property.

If the property was sold in the manner prescribed for the execution of court decisions, the property may not be seized on the grounds specified in the first part of this article.

If the property is received free of charge from a person who does not have the right to transfer it to another person, the owner has the right to claim the property in all cases.

Money, as well as securities listed as bearer, cannot be claimed from a bona fide holder.

According to Article 230 of the Civil Code, the owner has the right to demand the following when claiming property in accordance with Article 228 of the Civil Code:

to return or pay all income received or to be received from a person who knew or should have known that his possession was unlawful (unscrupulous possessor) during the whole period of possession of the property by that person;

and from the bona fide possessor - all income which he has received or is to be deducted from the time when he knew or should have known that his possession was unlawful, or from the time when the owner claimed it on the claim for property.

In turn, both the bona fide possessor and the unscrupulous possessor have the right to 
demand from the owner to pay the necessary expenses incurred on the property for as long as the income received from the property is to be returned to the owner.

If it is possible to separate the things that improve the thing without damaging the thing, the bona fide possessor has the right to keep these things. If it is not possible to separate such items, the bona fide possessor has the right to claim the costs incurred to improve the item, but these costs should not exceed the value added to the item (Articles 229-230 of the Civil Code).

As a general rule, property under trust management is recovered from both the bona fide possessor and the unscrupulous possessor. This is because both the honest possessor and the dishonest possessor are considered illegitimate possessors.

For example, in accordance with Article 34.8 of the Law of the Republic of Uzbekistan "On Mortgage" of October 4, 2006, if it is proved that the owner of the pledge letter knew or should have known this while possessing it, he is not considered the legal owner of the pledge letter.

Both the founder and the beneficiary of the management will have specific rights and obligations under the contract. First of all, the founder of the management has the right to control the legal and practical actions of the trust manager on the basis of the terms of the contract, without interfering with his operational and economic activities for the management of property. To do this, he has the right to receive relevant information and reports from the trustee within the period specified in the contract. If the founder of the management finds violations of the terms of the contract, he has the right to demand from the trustee to eliminate it within a reasonable time.

The question of whether the action of the founder of the management to transfer the property to trust management is his right or obligation has also caused a heated debate in the legal literature. Some authors believe that the transfer of property to trust management is the responsibility of the trust manager, while others the contract of trust management of property is a real contract emphasizes that the transfer of property to trust management is not part of the obligations of the founder [9-12].

In our opinion, the opinions of the authors of the second group are quite reasonable. After all, in a contract of trust management of property, the rights and obligations of the parties arise only after the transfer of property to a trustee, except for the conclusion of the contract, and the transfer of property to a trustee is not the obligation of the founder.

Unless otherwise provided by the contract, the founder of the management has the right to demand the transfer to him of the profits and income from his property transferred to the trust management.

If the contract of trust management of property provides for the payment of a fee to the trust manager, the founder of the management will have to pay to the trust manager the amount specified in the contract. Typically, this obligation is fulfilled by giving the trustee the right to withhold an appropriate portion of the income, profit, and 
other material benefits received from the property for the fees and expenses incurred by the trustee to be paid to him.

The founder of the management has no right to alienate, pledge and enter into other transactions related to the property transferred to the trust management. This rule follows from the requirements of Article 857 of the Civil Code. After all, it stipulates that during the term of the contract of trust management of property, the property rights in respect of it are exercised by the trust manager, not the founder of the management.

\section{CONCLUSION}

In a contract of trust management of property, the founder of management as a creditor must fulfill the obligations of the creditor. That is, he must submit all the information and documents about the property entrusted to the trust management in order for the trust manager to operate effectively, and provide information about his trusted and stable business partners. In addition, the founder of the management has no right to interfere in the operational and economic activities of the trust manager.

If the contract of trust management of the property is concluded in favor of a third party (beneficiary), the above rights of the founder of the management will belong to the beneficiary. However, the beneficiary also has the right to waive all the rights granted to him by the trustee of the property at any time and for no reason. In this case, the rights of the beneficiary pass to the founder or the newly appointed beneficiary acquires these rights.

\section{REFERENCES}

1. Walters-Kluver. (2002). Civil law. Vol. II. Textbook. M. 128 p.

2. Dozortsev V.A. (1996). Trust management of property (chapter 53). Civil Code of the Russian Federation. Part two. Text, comments, alphabetical-subject index / Ed. O.M. Kozyr, A.L. Makovsky, S.A. Khokhlova. M. 546 p.

3. Sergeeva, Yu.K. Tolstoy. (1997). Civil law: Textbook. Part 2./ Ed. A.P. M. 659 p.

4. Chukhnenko V.V. (2012). Legal status of the beneficiary in the property trust agreement: author. dis. Cand. legal. sciences. M. 23 P.

5. Egamberdieva N.H. (2007). Proceedings of the scientifictheoretical conference "Reflection of insurance and insurance contracts in the Civil Code of the Republic of Uzbekistan. Problems of improving the Civil Code." Toshkent: TDYul. pp. 157-160.

6. Ergashev V.Y. (2007). Some issues related to the legal nature of the vindication claim. Proceedings of the scientific-theoretical conference on "Problems of improving the Civil Code." Tashkent: TSU. pp.157-160.

7. Ergashev V.Y. (2005). Scientific and theoretical aspects of the emergence and abolition of the right of citizens to private property: PhD diss. Abstract. Tashkent: $16 \mathrm{p}$.

8. Imomov N. (2006). Protection of property rights of business entities. Tashkent: TSU. pp.14-15. 
Doi: https://doi.org/10.37547/tajpslc/Volume03Issue06-03

\section{Efimova L.G. (2001). Banking transactions: law and practice. M.: p.637.}

10. Civil law of Russia. Part two. Obligations law / Otv. ed. O.N.Sadikov. M.: 1997.578 p.

11. Mikheeva L.Yu. (1999). Trust property management. Ed. V.M. Chernov. M.: $141 \mathrm{p}$.

12. Civil law: In 2 volumes. Volume II. Polutom 2: Textbook / Otv. ed. E.A. Sukhanov. M.: BEK, 2002.128 p. 